\title{
ENTRE A FICÇÃO E A OBJETIVIDADE breve estudo sobre a crônica no jornalismo brasileiro durante a copa do Mundo de Futebol de 2002
}

\author{
ENTRE LA FICTION ET L'OBJECTIVITÉ: UNE BRÈVE ÉTUDE \\ DE LA CHRONIQUE DANS LE JOURNALISME BRÉSILIEN \\ PENDANT LE MONDIAL DE FOOTBALl 2002
}

\author{
José Carlos Marques* \\ Universidade Estadual Paulista - Bauru
}

\begin{abstract}
RESU M O
A Copa do Mundo de Futebol de 2002, disputada no Japão e na Coreia do Sul, representava um desafio inédito para a cobertura dos jornais brasileiros: oferecer um conteúdo atraente para o leitor diante dos prazos de edição e publicação, os quais antecediam em poucos momentos os horários das partidas do torneio. Uma das estratégias para combater a efemeridade do tempo da notícia foi a de recorrer à colaboração de escritores e cronistas. Convocados para comentar o evento, esses profissionais distanciaram-se da mera referência jornalística; assim, fatos e notícias reconstruídos passaram a adquirir contornos carregados de subjetividade e criação literária.
\end{abstract}

\section{PALAVRAS - CHAVE}

Crônica literária, Copa do Mundo de Futebol 2002, jornalismo brasileiro

A Copa do Mundo de Futebol de 2002, disputada no Japão e na Coreia do Sul, trazia a novidade de, pela primeira vez, contar com dois países-sede. $O$ torneio, realizado de 31 de maio a 30 de junho, representava um esforço inédito para a imprensa escrita brasileira: como oferecer ao leitor um produto atrativo diante de um fuso adiantado de 12 horas? Os prazos de fechamento dos jornais, normalmente por volta da meia-noite ou 1 hora da manhã, antecediam em poucos momentos os horários das partidas da Copa; estas já teriam acabado no momento em que as edições dos jornais chegassem às bancas, com as notícias do dia anterior.

Paralelamente a essa circunstância, a imprensa esportiva brasileira repetia, nesse Mundial, uma estratégia que se solidificou ao longo das décadas de 1980 e 1990: recrutar

\footnotetext{
*zeca.marques@faac.unesp.br
} 
escritores, cronistas e colunistas dos cadernos de "Cultura" - que não escreviam ordinariamente para a editoria de Esportes - para colaborar com a cobertura da Copa do Mundo. O fenômeno era contemplado especialmente pelos jornais paulistas e cariocas que, até o início do século 21, compunham o que se convencionou chamar no Brasil de "Grande Imprensa": casos dos cariocas O Globo e Jornal do Brasil, e dos paulistas O Estado de S. Paulo e Folha de S.Paulo. Neste artigo, nossa proposta é a de analisar o discurso dos escritores e cronistas convocados extraordinariamente por esses quatro jornais para cobrir a Copa de 2002, o que nos configura um corpus composto pelos textos de Luis Fernando Verissimo (colaborador de O Estado de S. Paulo e O Globo), José Roberto Torero, Marçal Aquino e Milton Hatoum (esses três, colaboradores da Folha de S.Paulo).

Partindo da afirmação de Antonio Candido, segundo a qual a crônica é um "gênero menor", ${ }^{1}$ verificamos como esse tipo de texto assentou-se tão confortavelmente numa editoria também considerada "menor" dentro do jornal - a seção de esportes. E por não ser um "gênero maior", a crônica ficou mais perto de seus leitores, ajustando-se à sensibilidade de todo o dia, por meio da elaboração de uma linguagem que fala de perto ao nosso modo mais natural. Por conseguinte, a crônica faz uso de grande despretensão, utiliza quase sempre o humor e pega o miúdo para mostrar nele uma singularidade insuspeitada. Além disso, a crônica não tem pretensões a durar: é filha do jornal e da era da máquina; não foi feita originariamente para o livro, mas para essa publicação efêmera (o jornal).

Ao analisar o papel da crônica no jornalismo moderno, os principais estudos sobre esse gênero apontam também para uma característica em comum: a de se tratar de um texto híbrido, que se aproxima da literatura ao mesmo tempo que dela se distancia, já que não deixa de assumir sua condição de texto também jornalístico. No caso dos textos publicados por ocasião da Copa do Mundo de 2002 e aqui analisados, os cronistas abdicaram do registro exclusivamente referencial dos fatos para abrir espaço ao comentário pessoal, ao olhar subjetivo, à busca do significado do efêmero e do fragmentário. A escolha dos temas é arbitrária, e sua forma mostra-se caleidoscópica, fragmentária e subjetiva, por meio de uma linguagem que renuncia aos cânones jornalísticos. Por isso o jargão jornalístico é esquecido no espaço da crônica, e esta acaba representando assim "um oásis de onde os chavões da imprensa, os clichês, as frases feitas, todas as características do estilo impresso, solene e empolado, são rigorosamente excluídos". ${ }^{2}$

A crônica debruça-se sempre sobre um fato moderno, que atende à fugacidade da vida das grandes metrópoles do capitalismo industrial; trata-se de um registro dos instantâneos da modernidade, dos acontecimentos chocantes do cotidiano das grandes cidades, advindos com o processo de urbanização e industrialização. Para o crítico Davi Arrigucci, esse tipo de gênero define uma forma de memória, um meio de representação temporal de fatos passados, ao mesmo tempo que tece a continuidade do dia a dia. Nesse movimento, a crônica adquire espessura de texto literário, "pela elaboração da linguagem, pela complexidade interna, pela penetração psicológica e social, pela força poética ou pelo humor, uma forma de conhecimento de meandros sutis de nossa realidade e de nossa história". ${ }^{3}$ Uma opção da

${ }^{1}$ CANDIDO. A vida ao rés-do-chão.

${ }^{2}$ RONÁI. Um gênero brasileiro: a crônica, p. 212.

${ }^{3}$ ARRIGUCCI. Fragmentos sobre a crônica, p. 53. 
crônica, assim, é partir para a prosa de ficção, mantendo ênfase num mundo recriado imaginariamente - daí ela poder se confundir com o conto, com a narrativa satírica ou com a confissão. Arrigucci circunscreve ainda a crônica ao projeto dos modernistas brasileiros, devido à decisiva incorporação, pelo texto escrito, da fala coloquial, que se ajustava perfeitamente à observação dos fatos da vida cotidiana numa forma comunicativa próxima do leitor.

A par esses fatores, o tempo continua sendo a matéria-prima do cronista, mas a crônica moderna tem como marca identitária o fato de ser um comentário ou uma narrativa quase impressionista. Predomina o caráter subjetivo do "eu", o qual não se mascara no discurso da imprensa escrita. Trata-se de uma cumplicidade que se quer estabelecida com os leitores e que se apoia na relação de simpatia que o autor experimenta com seu público: "os textos literários beneficiam-se ademais de uma recepção 'hiperprotegida', na qual o leitor concede um máximo de crédito ao autor."” No caso específico do futebol, abrem-se inúmeras possibilidades para que o imaginário e a inventividade do espetáculo contaminem os textos dos cronistas, por meio de relatos em que ficção e realidade se misturam, perpetuando uma herança advinda das locuções radiofônicas. O rádio, ao oferecer a transmissão ao vivo das partidas nas Copas do Mundo (procedimento que, no Brasil, solidificou-se a partir dos anos 1950), ocupou um lugar distinto no imaginário do aficionado de futebol, como atesta Décio de Almeida Prado:

O rádio, na voz exaltada dos locutores, dava aos jogos da época uma vibração que eles jamais tiveram, antes ou depois, com tamanha intensidade. É como se estivéssemos à beira do campo, seguindo a bola de pé em pé, porém libertos das limitações que a realidade impõe à imaginação, e, sobretudo, sem o implacável testemunho da televisão. Não havia partida que não tivesse contornos épicos. ${ }^{5}$

O filósofo francês Jean Baudrillard debruça-se sobre a questão ao analisar como esse "implacável testemunho da televisão" acaba por ser mais forte do que o próprio acontecimento esportivo em si. Em 1987, durante a realização do campeonato europeu de clubes, uma partida entre a equipe espanhola do Real Madrid e o Napoli, da Itália, foi interrompida devido a distúrbios causados por torcedores. $\mathrm{O}$ jogo voltou a ser disputado posteriormente, mas com portões fechados ao público e apenas com a presença de organizadores, atletas e jornalistas:

Sorte d'anticipation chirurgiale de nos événements futurs: un événement tellement minimal qu'il pourrait ne pas avoir eu lieu du tout, et une amplification maximale sur l'écran. Personne n'en aura vécu les péripéties, mais tout le monde en aura capté l'image. (...) C'est comme si une Fédération Politique Internationalle avait suspendu le public pour une durée indéterminée et l'avait expulsé de tous les stades pour garantir le déroulement objectif du match. C'est cela notre scène transpolitique: cette forme transparante d'un espace public d'où les acteurs ont été retirés, cette forme pure d'un événement d'où les paissons se sont retirées. (...) Tout référent doit disparaître pour que l'événement soit acceptable sur l'écran mental de la télévision. ${ }^{6}$

\footnotetext{
${ }^{4}$ MAINGUENEAU. Pragmática para o discurso literário, p. 29.

${ }^{5}$ ALMEIDA PRADO. Latejando com o futebol, p. 204.

${ }^{6}$ BAUDRILLARD. Mirroir du terrorisme, p. 86-87.
} 
Se Baudrillard se revolta contra a tirania da "tela mental da televisão", capaz de fazer desaparecer todo o referente da paixão que o público poderia suscitar, temos no entanto que, apesar do advento da televisão, não se esgotaram as possibilidades de reconstrução imagética do fato esportivo mediado.

Os cronistas presentes na cobertura das Copas do Mundo também efetuam, em maior ou menor grau, esse movimento de libertação das limitações que a realidade impõe à imaginação - a despeito da presença de outros instrumentos de mediação do fato, como a televisão ou o rádio. Assim, passam a criar relatos fictícios sobre fatos ligados ao evento, ou simplesmente criam histórias isoladas, quase atemporais, que não mantêm vínculo algum com a competição em jogo. Luis Fernando Verissimo, por exemplo, brinca com a presença do videoteipe, ao elegê-lo como versão acabada da partida vista ao vivo:

O verdadeiro jogo é o videoteipe. O jogo acontecendo na hora é apenas a matéria-prima do que veremos depois, descansadamente, sem as incertezas e o nervosismo do momento. Enfim, sem a distração da realidade. Brasil e Turquia visto depois foi outro jogo. Ou foi a versão acabada do esboço que vimos ao vivo. No tape, por exemplo, Rivaldo foi muito melhor.?

Verissimo também procura superar a "distração da realidade", com o uso do videoteipe, que, ao permitir o esclarecimento de lances e jogadas, oferece exatamente um outro real, que poderíamos chamar de "virtual" e que pode desvincular-se do próprio lance ou da jogada em si que lhe deu origem. Por isso Rivaldo "apresentou-se" melhor no videoteipe do que no jogo. Ou como analisa o crítico italiano Omar Calabrese,

As novas tecnologias audiovisuais anulam a confiança na verificação pessoal dos factos. Não é a visão directa do jogo de futebol que dá a ilusão da verdade, mas a sua revisão na televisão ao retardador. A técnica de representação produz objectos que são mais reais do que o real, mais verdade do que a verdade. Mudam deste modo as conotações da certeza. ${ }^{8}$

Pode-se referir aqui como essa particularidade da crônica de criar novas imagens e enredos inclui-se na análise de Roland Barthes sobre a narrativa, entendida pelo crítico francês como elemento próprio da condição humana. Se nas Mil e uma noites temos que a personagem Sherazade narra inúmeros contos e lendas do Oriente, noite após noite, para não ser assassinada pelo rei Chariar, também o homem sente a necessidade de manter em moto-contínuo esse processo de contar histórias - se não o fizer, está igualmente fadado a morrer:

A narrativa pode ser sustentada pela linguagem articulada, oral ou escrita, pela imagem, fixa ou móvel, pelo gesto ou pela mistura ordenada de todas essas substâncias; está presente no mito, na lenda, na fábula, no conto, na novela, na epopéia, na história, na tragédia, no drama, na comédia, na pantomima, na pintura (recorde-se a Santa Úrsula de Carpaccio), no vitral, no cinema, nas histórias em quadrinhos, no fait divers, na conversação. Além disto, sob estas formas quase infinitas, a narrativa está presente em todos os tempos, em todos os lugares, em todas as sociedades; a narrativa começa com a própria história da humanidade. ${ }^{9}$

\footnotetext{
${ }^{7}$ Luis Fernando Verissimo. O Estado de S. Paulo, 5 jun. 2002.

${ }^{8}$ CALABRESE. A idade neobarroca, p. 69.

${ }^{9}$ BARTHES. Introdução à análise estrutural da narrativa, p. 18.
} 
Entre os textos produzidos pelos cronistas sobre a Copa de 2002, destaca-se assim a forte presença de "textos narrativos artificiais", segundo distinção observada na obra do professor português Vítor Manuel de Aguiar e Silva: esses relatos seriam produzidos em peculiares contextos de enunciação, com uma intencionalidade alheia à interação comunicativa dos "textos narrativos naturais", que são aqueles presentes na vida cotidiana ordinária. Além disso, os "textos narrativos artificiais" se estabeleceriam, na maior parte dos casos, sob convenções determinadas e obedecendo a códigos específicos. ${ }^{10}$ Todo texto narrativo se caracteriza, portanto, pela existência de uma instância enunciadora que relata eventos reais ou fictícios, que se sucedem no tempo e no espaço, independentemente dos tipos de personagens aí implicados. Cabe dizer, porém, que narrar nem sempre é criar literatura - caso contrário, qualquer notícia de jornal que relatasse algum fato (a rebelião de presos em determinada penitenciária, por exemplo) poderia ser entendida como obra literária. Dominique Maingueneau alarga a discussão ao afirmar que é da essência do discurso literário não fazer coincidir o narrador com o escritor, e que um relato ficcional não representa, necessariamente, um discurso literário: "Uma das singularidades do discurso literário é precisamente tornar problemática a própria noção de enunciador, dissociar o indivíduo que escreve das representações do autor que a instituição literária permite definir." ${ }^{11}$ É por isso que, no texto narrativoliterário, estabelece-se uma polaridade entre o autor textual e o mundo narrado, que se reproduz na representação de um tempo e de um espaço próprios, nos quais se processa a sequência de eventos propostos pelo narrador.

Marçal Aquino, jornalista, escritor e roteirista de cinema (escreveu os roteiros dos longas-metragens $\mathrm{O}$ invasor, Ação entre amigos e Os matadores), constitui-se no melhor exemplo de produtor de "textos narrativos artificiais" ao longo do Mundial do Japão e Coreia do Sul, ao apresentar crônicas semanais que misturavam realidade e ficção. Aquino retoma assim uma tradição perpetuada na década de 1980, especialmente pelo Jornal do Brasil, que já em 1982 mantinha a série intitulada "Operação Tetra", de autoria de Carlos Eduardo Novaes, com uma narrativa ficcional sobre dois torcedores brasileiros - Biguá e Cuíca - que foram torcer pelo Brasil na Espanha. O mesmo Jornal do Brasil repetiria a iniciativa em 1990, ao publicar colunas de autoria de Joaquim Ferreira dos Santos que narravam o dia a dia da seleção nacional com recursos humorísticos próprios da crônica de jornal. E, ainda em 1990, outra iniciativa do gênero seria protagonizada pelo escritor João Antônio, contratado por O Estado de S. Paulo. Em sua crônica diária, intitulada "Histórias de torcedor", João Antônio poucas vezes se referiu à Copa disputada na Itália, oferecendo ao leitor narrativas e histórias sobre torcedores e outros casos ligados ao universo do futebol.

Em 29 de maio de 2002, Aquino publicou a crônica "Peneira", em que retrata o sonho que um garoto pobre alimenta de tornar-se jogador de futebol. Para tanto, é preciso passar pelos testes que os clubes de futebol realizam à procura de jovens talentos:

${ }^{10}$ AGUIAR E SILVA. Teoria da literatura, p. 597-598.

${ }^{11}$ MAINGUENEAU. Pragmática para o discurso literário, $\mathrm{p} 28$. 
Eles começam a chegar bem antes da hora marcada. Sentam-se na beira do campo de um jeito tímido, um distante do outro. A maioria veste roupas surradas, e todos seguram suas chuteiras como se fossem coisas preciosas. Um mulatinho franzino encosta-se no alambrado e olha com curiosidade para o menino loiro que está chegando, o único acompanhado por um adulto, o pai, na certa. O homem examina os outros meninos, como se estivesse avaliando as chances de cada um, e parece satisfeito com o que vê. ${ }^{12}$

A atemporalidade do texto aproxima-o das crônicas escritas por João Antônio em 1990, e a narrativa domina a cena do começo ao fim, por meio do desencadeamento de ações que retratam o desempenho dos garotos. O narrador em terceira pessoa, onisciente, anuncia o resultado final da "peneira" (quais foram escolhidos, quais reprovados) e, no final, surpreende o leitor incluindo a narrativa no plano onírico do personagem. $\mathrm{O}$ enredo envolve ainda os estereótipos sociais ligados ao mundo do futebol (negro órfão e pobre disputa espaço com o loiro rico, que está acompanhado do pai).

$\mathrm{Na}$ semana seguinte, temos a crônica "Um guerreiro sai de cena", em que o narrador faz referências a determinado jogador que "chegou a jogar um tempo com Pelé" e que é chamado o tempo todo pelo epíteto de "guerreiro". O texto não nomeia em nenhum momento o atleta (depreende-se que seja o atacante Toninho Guerreiro, artilheiro do Santos no início da década de 1970) e retrata com saudosismo o período de glórias do craque, que agora se encontra na miséria, defendendo um clube pequeno, mas ainda com a genialidade de outrora:

Os refletores já estavam acesos e parte da torcida deixava o estádio quando vi a mágica acontecer. Ele recebeu a bola no meio-campo e arrancou em direção à área adversária. Chutou sem estilo, de bico, um segundo antes de ser atingido pelo zagueiro. A bola entrou no ângulo. Seu time ganhou sobrevida na segunda divisão. A caminho do vestiário, mancando, com a camisa do clube no ombro - os times eram pobres, não havia a tradicional troca de camisas após os jogos -, ele passou por mim e fez sinal de positivo. Um torcedor gritou seu nome junto ao alambrado. Ele parou e acenou. O halo que o contornava, naquela iluminação de boate, parecia mais fraco. Mas brilhava. Naquele momento, ele era um deus cansado, em fim de carreira. Mas ainda assim um deus. ${ }^{13}$

Nessas duas crônicas, vemos como o encadeamento das ações, no tempo e no espaço, revela os recursos próprios do texto narrativo, que

comporta como elemento estrutural relevante da sua forma de conteúdo a representação do tempo: do tempo-cronologia, que marca a sucessão dos eventos; do tempo concreto, do tempo como durée na acepção bergsoniana deste termo, que modela e transforma os agentes; do tempo histórico, que subsume o tempo-cronologia e o tempo concreto, que configura e desfigura os indivíduos e as comunidades sociais. ${ }^{14}$

Temos aqui duas histórias construídas de modo ficcional, em que o narrador procura reconstruir os fatos observados de maneira literária, ao estender a polaridade entre o autor textual e o mundo narrado, conforme referido por Vítor Aguiar e Silva. O enredo dessas crônicas, aliás, mantém grande familiaridade, não por acaso, com o conto "Abril,

\footnotetext{
${ }^{12}$ Marçal Aquino. Folha de S.Paulo, 29 maio 2002.

${ }^{13}$ Marçal Aquino. Folha de S.Paulo, 5 jun. 2002.

${ }^{14}$ AGUIAR E SILVA. Teoria da literatura, p. 603.
} 
no Rio, em 1970”, de Rubem Fonseca, publicado em 1975 no livro Feliz Ano Novo. Aqui, o protagonista é um jovem jogador de futebol que sonha chegar ao estrelato e ser convocado para a seleção brasileira, cujos treinos preparatórios para a Copa do Mundo do México, disputada em junho de 1970, são assistidos por ele na época e na cidade descritos no título do conto. Para poder treinar num clube grande do Rio, o jovem precisa ser submetido aos testes e à longa caminhada de reconhecimento dos jogadores anônimos, até que seja descoberto, em meio ao time de várzea em que joga, por algum boleiro. Daí um dos leitmotivs do conto ser a frase "O Jair da Rosa Pinto já chegou?", que se repete ao longo de toda a narrativa, numa representação messiânica do ex-jogador Jair de Rosa Pinto, craque do passado que assume agora o status de divindade capaz de oferecer um mundo novo de glórias e realizações.

Prosseguindo na construção das narrativas, em 12 de junho de 2002 (data em que se comemora no Brasil o "Dia dos Namorados"), Aquino começou a introduzir elementos ligados à Copa do Mundo em seu relato, ao publicar a crônica "Paixão de torcedor" uma história sobre duas pessoas que se apaixonam após se conhecerem na rua:

Shirley tinha cabelos loiros (de farmácia), um rosto de traços bonitos, olhos esverdeados e um corpo que o Instituto de Pesos e Medidas aprovaria sem nenhuma ressalva. Agenor apreciou o conjunto e, na segunda vez em que a encontrou, num ponto de ônibus da linha Parque Bristol-Praça do Patriarca, puxou conversa. Os dois se gostaram logo de cara. Ele era gentil e engraçado; ela, atenciosa e sorridente. Passaram a esperar todos os dias pelo mesmo ônibus. Agenor trabalhava numa loja de ferragens na Florêncio de Abreu, e Shirley era caixa numa perfumaria da rua Direita. ${ }^{15}$

Pela primeira vez, seu texto traz referências explícitas e concretas a respeito do espaço da ação, compondo um cenário tipicamente paulistano (rua Direita, rua Florêncio de Abreu, Praça do Patriarca). Os personagens também ganham destaque pela construção dos caracteres (a moça tem cabelos loiros de farmácia, o que se relaciona com o fato de trabalhar como caixa de uma perfumaria; o rapaz é funcionário de uma loja de ferragens e aprova o "conjunto" da moça como se fora um teste do Instituto de Pesos e Medidas). A sequência da crônica mostra os desdobramentos da relação amorosa:

Apaixonados, resolveram viver juntos. Mas havia um detalhe a respeito de Shirley que Agenor desconhecia: ela era palmeirense. Devotada a ponto de frequentar estádios e participar de torcida organizada. Uma fanática, na verdade. Você conhece quantas mulheres com coragem suficiente para tatuar na pele o símbolo do time de coração? Shirley tinha o escudo do Verdão tatuado no corpo, num lugar tão secreto que você só descobriria se cruzasse com ela num campo de nudismo.

Ele ficou passado quando descobriu. Agenor era corintiano, roxo. Mais que isso: um antipalmeirense. Soltava foguetes sempre que o rival era derrotado. Apesar de tudo, os dois viviam bem.

(...)

Quando o Palmeiras eliminou o Corinthians numa semifinal de Libertadores, ela pegou tão pesado nas provocações que Agenor resolveu sair de casa e foi morar num cômodo nos fundos da casa da irmã. Shirley e Agenor passaram um bom tempo separados.

(...)

${ }^{15}$ Marçal Aquino. Folha de S.Paulo, 12 jun. 2002. 
Durante a Copa, o casal fez uma trégua e tem assistido aos jogos do Brasil com interesse. É verdade que Shirley torce mais pelo goleiro Marcos do que pelo resto do time. E também é verdade que, na opinião de Agenor, a seleção só conquistará o penta se Felipão colocar Ricardinho no time. Agenor e Shirley estão felizes: em breve, vai chegar o primeiro filho dos dois. Ela espera que seja uma menina. Um menino pode gerar confusão. Nem morta quer um filho chamado Vampeta. ${ }^{16}$

O cenário de amor idílico do início é alterado pela rivalidade clubística dos personagens, mas a ordem se restabelece pelo armistício proposto pelos actantes. Entretanto, o final da crônica mostra que a tensão inicial continua se manifestando no texto por meio dos pressupostos (Marcos, goleiro da seleção, jogava no Palmeiras na época da Copa, enquanto Ricardinho pertencia ao Corinthians) e por meio da ironia (a recusa de chamar o filho de "Vampeta" se explica tanto pelo caráter esdrúxulo do nome como pelo fato de se referir a um jogador corintiano, também presente no grupo da seleção brasileira). Além disso, reproduzem-se ainda algumas das funções estruturais analisadas por Vladimir Propp no conto maravilhoso russo. A crônica insere-se no modelo de narrativa que obedece ao esquema clássico "ordem existente - ordem perturbada ordem reestabelecida"; além disso, temos a figura da vítima (objeto da perturbação), do vilão (sujeito da perturbação) e do herói (sujeito do restabelecimento da ordem) - que no fundo são representadas ao mesmo tempo pelos dois personagens.

Ao contrário das crônicas anteriores, "Paixão de torcedor" inclui pela primeira vez referentes relacionados com a Copa do Mundo (casos dos jogadores citados, por exemplo). O mesmo seria visto na crônica de 26 de junho, "Dia de decisão", em que o cotidiano de um motorista de táxi alcoólatra é retratado em meio às comemorações da torcida brasileira com um gol de Ronaldo:

Naquele momento, Ronaldinho encaçapou uma bola no ângulo dos ingleses, e os cinco caras pularam para o meio da rua e descarregaram suas armas. Quando viu que eles recarregavam a munição, Everaldo tomou uma decisão. ${ }^{17}$

A ausência de narratividade seria intensificada por Aquino na crônica do dia 19 de junho, intitulada "A hora $\mathrm{H}$ dos craques", em que o escritor abandona o teor ficcional dos demais textos e iguala-se aos comentários dos "entendidos":

Não dá para saber o que vai acontecer com o Brasil nesta Copa. Tendo chegado a duras penas às quartas-de-final (precisava todo aquele sufoco contra uma seleção modesta como a Bélgica?), o time ainda permanece uma incógnita. É capaz de qualquer coisa, principalmente a defesa. O torcedor brasileiro vive neste momento mais de esperanças do que de certezas. Não custa, portanto, ter mais uma esperança: a de que alguns craques joguem na seleção o mesmo futebol que jogam em seus clubes. ${ }^{18}$

O texto resvala para o simples comentário. Contudo, a despeito dessa última crônica, cabe dizer que o caráter ficcional e atemporal das demais incluem a sequência de relatos de Marçal Aquino num plano distinto do que vimos até então. Os demais

\footnotetext{
${ }^{16}$ Marçal Aquino. Folha de S.Paulo, 12 jun. 2002.

${ }^{17}$ Marçal Aquino. Folha de S.Paulo, 26 jun. 2002.

${ }^{18}$ Marçal Aquino. Folha de S.Paulo, 19 jun. 2002.
} 
cronistas analisados, mesmo quando relatam histórias, não tornam problemática a "noção do enunciador", ou seja, não dissociam de maneira tão intensa e explícita o indivíduo que escreve das representações do autor, como conceitua Maingueneau. Não se observa, nos casos analisados até agora, aquela "polaridade entre o autor textual e o mundo narrado”. A circulação e publicação das crônicas em livros parece justamente ratificar a condição literária desses textos, em que o trabalho linguístico reforça o caráter estrutural da obra:

(...) faz parte da essência da literatura a obra poder circular em tempos e lugares muito afastados dos de sua produção. Essa "descontextualização" é o correlato da ambigüidade fundamental da obra literária, que perdura fechando-se sobre si, submetendo-se a regras bem mais coercitivas que as da linguagem comum. ${ }^{19}$

Ao longo da Copa de 2002, o autor que mais se aproxima da construção narrativa de Marçal Aquino é o também roteirista e escritor José Roberto Torero, que incorpora aos textos escritos ao longo da competição, por exemplo, alguns dos personagens fictícios criados por ele em crônicas anteriores. Dentre os personagens criados pelo cronista, o que estabelece maior narratividade no discurso é Leocádio, também chamado de Lelê, apresentado como sobrinho de Torero. Vejamos os dois exemplos:

A abertura da Copa do Mundo é uma coisa que tem uns caras que fazem discursos, aí tem uns fogos, depois vêm umas pessoas com roupas estranhas que andam de um lado para o outro e isso dá o maior sono. Então os jogadores cantaram e o jogo começou. O que eu mais gostei foi que, quando saiu o gol do Senegal, o jogador pôs a camisa no chão e todo o time dançou em volta dela. Eu também tirei a minha camisa, joguei no meio da sala e comecei a pular, mas a minha mãe falou: "Pega já essa camisa que isso não é pano de chão!”20

O gol que eu achei mais bacana foi o do Edmilson, que deu uma pirueta que nem a que eu faço na cama da minha mãe quando ela não está em casa. Aposto que a mãe do Edmilson deixava ele treinar na cama dela. Quando acabou o jogo, todo mundo se abraçou e ficou contente, e aí eu pensei: Hoje é o dia mais feliz da minha vida! Mas aí a minha mãe pegou e falou: - Lelê, vai tomar banho. Daqui a pouco você vai para a escola. E aí eu pensei: Hoje é o dia feliz mais infeliz da minha vida. ${ }^{21}$

Lelê configura-se como um narrador-criança, em que a linguagem enunciada tenta aproximar-se do universo infantil e do discurso da criança, por meio de frases curtas ("e aí eu pensei”, "deixava ele treinar", "minha mãe pegou e falou”) e do recurso recorrente ao discurso direto ("mas a minha mãe falou: 'Pega já essa camisa que isso não é pano de chão!’”).

Já no texto que inaugura sua participação no caderno "Copa" da Folha de S.Paulo, Torero estabelece um "contrato de casamento" com seus leitores e promete escrever sempre os seus textos, "a não ser, é claro, quando não tiver nenhuma idéia. Nestes dias serei substituído por meu sobrinho Leocádio, pelo grande Zé Cabala ou por um outro

\footnotetext{
${ }^{19}$ MAINGUENEAU. Pragmática para o discurso literário, $\mathrm{p} 31$.

${ }^{20}$ José Roberto Torero. Folha de S.Paulo, 1 jun. 2002.

${ }^{21}$ José Roberto Torero. Folha de S.Paulo, 14 jun. 2002.
} 
qualquer". ${ }^{22} \mathrm{O}$ cronista estende ainda mais a metalinguagem, ao interpor seu texto no universo da ficção e do imagético, com a promessa de que irá

(...) colocar a exatidão acima de tudo, a não ser, é claro, nos casos em que a imaginação se mostrar mais interessante. As Copas, reconheçamos, têm muito mais a ver com as lendas do que com a verdade..$^{23}$

À semelhança do que já havia realizado por ocasião da Copa de 1998, Torero investe novamente na simpatia do público ("Caros leitores"), e abusa do uso de adjetivos, ao compor com ironia o quadro (irreal) de sua enunciação na crônica "Ode ao pingado e ao pão com manteiga":

Caros leitores, estou salivando. E não há diante de mim nenhuma foto da Ana Paula Arósio. É algo ainda mais saboroso, ainda mais voluptuoso. Estou escrevendo este texto no balcão de uma padaria e à minha frente há um cálido café com leite e um dourado pão com manteiga na chapa. Uma ondulante fumaça sobe do copo. E do pão vem um cheiro inebriante. E eis aí uma das grandes vantagens desta Copa do Mundo na Ásia, que começa na próxima sexta-feira: ela nos fará saborear esse manjar com o devido respeito. ${ }^{24}$

O prosaísmo do plano descritivo ("Estou escrevendo este texto no balcão de uma padaria") apoia-se na diversidade dos adjetivos ("voluptuoso", “cálido", "ondulante”, "inebriante", etc.), que recheiam o café da manhã do locutor. Esse recurso, que aproxima o texto da composição literária, é ainda mais intenso na crônica em que Torero analisa a derrota da seleção portuguesa na Copa e brinca com as variantes lingüísticas de nosso idioma em Portugal e no Brasil. Temos aqui o texto e o supratexto, o "original" e a "tradução":

Um desaire, pá!, assim se pode qualificar o malogro lusitano na peleja da jornada matutina de ontem. É verdade que a equipa empenhou-se na busca da viragem, mas os estadunidenses, fechadinhos na carapaça, deram um figo ao Figo e triunfaram incontestavelmente. O guarda-redes teve lá suas fífias, o Rui Costa foi pouco interventivo como municiador, e o João Pinto e o avançado Pauleta andaram em profunda crise anímica. Nem o Sérgio Conceição teve muita gênica. A sonhadora falange de apoio esperava túneis, cabritas, golos de encher a vista, mas o que se viu, isto sim, foi a tradicional camisola verde-rubra desonrada. A massa adepta pensava que o selecionado estaria na posição cimeira, mas divide o rabo da bicha com os polônios. É gira isto ou não é?

Agora a tradução:

A maior decepção, meu! Não tem outro jeito de falar da derrota de Portugal. É verdade que eles tentaram a virada, mas os americanos, retrancadinhos lá atrás, não tomaram conhecimento do Figo e venceram mole, mole. O goleiro andou bobeando, o Rui Costa fez poucos lançamentos, e o João Pinto e o atacante Pauleta estavam desligadões. Nem o Sérgio Conceição mostrou a energia de sempre. O pessoal das padarias esperava bolas por debaixo das pernas, chapéus e gols, mas nada, o time não honrou a camisa. A torcida achava que a seleção estaria em primeiro lugar na tabela, mas agora divide a lanterninha com a Polônia. Coisa de louco! ${ }^{25}$

\footnotetext{
22José Roberto Torero. Folha de S.Paulo, 27 maio 2002.

${ }^{23}$ José Roberto Torero. Folha de S.Paulo, 27 maio 2002.

${ }^{24}$ José Roberto Torero. Folha de S.Paulo, 28 maio 2002.

${ }^{25}$ José Roberto Torero. Folha de S.Paulo, 6 jun. 2002.
} 
Além de Marçal Aquino e José Roberto Torero, outros escritores também puderam oferecer, sob diferentes maneiras, textos em que a construção ficcional ou a aproximação com a literatura se destacaram diante da produção ordinária das reportagens esportivas. Luis Fernando Verissimo, por exemplo, provoca a inclusão da literatura no mundo da Copa do Mundo por meio de um entrelaçamento de valores que surpreende pelo choque da hipérbole:

O que eu estou fazendo, conversando com a Fay Weldon em Sidney em vez de perguntando ao Felipão o que muda na sua filosofia com o Juninho Paulista? Pois é, antes da minha missão na Coréia houve este interlúdio no Festival de Escritores: um pouco de amenidade antes do grave engajamento intelectual da Copa. ${ }^{26}$

De um lado, temos o Festival de Escritores, que configuraria o paradigma de composição de elementos ditos da cultura do "alto" (o locutor mantém contato com outra autora literária, Fay Weldon). Entretanto, esse mesmo festival seria caracterizado como uma "amenidade". Do outro lado, no paradigma de composição de elementos da cultura do "baixo", teríamos a Copa, que aparece caracterizada como momento de "grave engajamento intelectual”. A inversão de valores pelo contraste inusitado faz com que o lado sério da vida seja aquele que esteja circunscrito ao universo do futebol: é mais importante se perguntar quais as mudanças provocadas na "filosofia" do técnico Felipão com a entrada de um determinado jogador no time. Os elementos de um e de outro mundo entrecruzam-se e se mesclam, potencializando e estendendo a linguagem para sua autorreferenciação lúdica e metalinguística

Para completar as relações que se estabelecem entre literatura e futebol, resta citar a grande ocorrência de referências e intertextos que permeiam os textos dos cronistas estudados no Mundial do Japão e Coreia do Sul. A fim de justificar a improbabilidade de alguns resultados dos jogos, por exemplo, Luis Fernando Verissimo cria dois personagens fictícios:

Difícil chegar a alguma conclusão geral sobre o futebol atual com os resultados da primeira fase, salvo a de que, com todo o mundo jogando mais ou menos igual, o Fortuito e o Aleatório - aquela imarcável dupla de área - decidiram mais jogos do que seria comum. ${ }^{27}$

Essa "imarcável dupla de ataque", formada pelo Fortuito e o Aleatório, não faz outra coisa senão referir o célebre Sobrenatural de Almeida, a "entidade" com nome e sobrenome que Nelson Rodrigues celebrizou em suas crônicas sempre que pretendia representar o imponderável ou explicar o acaso e a imprevisibilidade que cercam a atmosfera do mundo futebolístico. Em outra esfera distinta, Verissimo faz comovente homenagem ao escritor Roberto Drummond, falecido ao longo da Copa de 2002 (o cronista foi o único a se referir ao acontecimento, dentre o grupo de autores aqui analisado):

Soubemos da morte do Roberto Drummond antes de começar o jogo Brasil e Inglaterra. Me contaram que ele viria para a Copa mas desistiu, temendo ter algum problema longe de casa. Era um apaixonado por futebol. Aqui, provavelmente descreveria o time brasileiro

\footnotetext{
${ }^{26}$ Luis Fernando Verissimo. O Estado de S. Paulo, 31 maio 2002.

${ }^{27}$ Luis Fernando Verissimo. O Estado de S. Paulo, 15 jun. 2002.
} 
como o Gilberto Silva e assessoria, pois gostava do Atlético Mineiro acima de todas as coisas. Eu admirava nele o que admiro em outros intelectuais brasileiros que compartilham a mesma paixão, o fato de nunca escreverem com condescendência sobre o futebol. $\mathrm{O}$ que não significa tentar fazer do futebol, literariamente, mais do que ele é. Não se precisa buscar a referência maior, ou uma justificativa "artística" para o texto sobre o futebol: basta tratá-lo com o respeito que merece toda forma de superação humana para ele ter drama e grandeza suficientes, sem os artifícios da imaginação ou da retórica. O Drummond escrevia com simplicidade sobre a sua paixão, certo de que qualquer paixão já é complexa e misteriosa só por existir. ${ }^{28}$

As intertextualidades também são observadas sob outras formas. José Roberto Torero parodia uma própria composição sua sobre um poema de Vinícius de Morais e a recoloca humoristicamente na crônica "Replágio de um poema sobre o sábado":

Hoje é sábado, ontem foi sexta,

Remelento, acabo de acordar.

Meu desejo é continuar a sesta,

Mas é dia do Brasil jogar.

Porque hoje é sábado,

No pão passo margarina

E rezo pela derrota da China.

Porque hoje é sábado.

(...)

P.S.: Na Copa-98 já havia utilizado esse poema. O ladrão sempre volta ao local do crime. ${ }^{29}$

É no entanto com o romancista Milton Hatoum que se dá a mais original relação de intertextualidade entre futebol e literatura ao longo da Copa de 2002: o autor demonstra como o futebol dá margem a lances e acontecimentos que têm correspondência e representação no mundo literário. Convidado pelo editor do Caderno de Esportes da Folha de S.Paulo a escrever quatro crônicas durante a Copa, Hatoum não pôde aceitar de imediato devido a compromissos profissionais em Londres. Só que, ao retornar ao Brasil, o convite foi renovado, mas apenas duas crônicas acabaram sendo publicadas. Na primeira delas, o autor comenta a eliminação da Argentina da Copa e a expectativa dos ingleses diante da partida:

Bem-aventurada a Copa na Ásia, que dá aos insones um pouco de ânimo e emoção nas noites maçantes e quase sem fim. A vantagem de ser um corujão insone é que às três da madrugada estamos tão acesos quanto os torcedores no outro lado do mundo, em plena tarde de verão. Mas a insônia é uma espécie de pesadelo em noites passadas em branco. Pensei nisso quando vi a eliminação da Argentina. Impossível não vir à mente um conto de Jorge Luis Borges: "Funes, o memorioso". É um relato sobre a insônia, a eterna vigília de uma personagem que se lembra de tudo com os mínimos detalhes. Lembrar-se de tudo é o pesadelo dos que nunca dormem, ou dos que não se esquecem de nada. Nesse conto, Borges, um escritor "meramente argentino", fala da memória histórica e individual: a memória atroz de Irineo Funes e, por meio dele, a da Argentina. ${ }^{30}$

\footnotetext{
${ }^{28}$ Luis Fernando Verissimo. O Estado de S. Paulo, 23 jun. 2002.

${ }^{29}$ José Roberto Torero. Folha de S.Paulo, 8 jun. 2002.

${ }^{30}$ Milton Hatoum. Folha de S.Paulo, 17 jun. 2002.
} 
Assisti ao jogo Argentina x Inglaterra num bar do Soho, em Londres. A fumaceira dos cigarros incomodava menos que o silêncio, fruto do temor das tabelas rápidas e fulminantes, dos dribles e arrancadas dos argentinos. Uns segundos antes do pênalti que deu a vitória à Inglaterra, cutuquei um colega inglês, Alex Bellos, autor de um livro sobre o futebol brasileiro, e vaticinei: vocês venceram. Alex apenas murmurou: "Calma, vamos ver...". O gol provocou uma explosão de alegria no bar; logo depois voltaram o silêncio e o medo, só comparáveis ao silêncio estarrecedor e ao calafrio no conto "A queda da casa de Usher", de Allan Poe. ${ }^{31}$

Inicialmente, o drama da desclassificação dos argentinos apoia-se em Jorge Luis Borges. Aqui, o autor do conto "Funes, o memorioso" é referido quase que em forma de epígrafe, em que a insônia tratada no relato ficcional serve de referência para retratar a melancolia da derrota. Em seguida, é singular que seja citada a atmosfera que envolve um dos mais conhecidos contos de Edgard Allan Poe (norte-americano que viveu algum tempo na Inglaterra) para representar a angústia coletiva dos torcedores britânicos diante de uma partida decisiva. Na segunda e última crônica, Hatoum estabelece uma correlação formidável entre um conto de Julio Cortázar e o acontecimento inusitado que envolveu o uniforme de um dos jogadores brasileiros, na decisão do Mundial:

A certa altura do segundo tempo da partida final, um lance sem bola me pareceu fantástico. O jogo foi paralisado para que Edmilson pudesse trocar a camisa rasgada. Edmilson tentou várias vezes vestir a camisa nova. Não dava certo. A cabeça entrava por uma das mangas, os braços pelo buraco da cabeça, ou a cabeça e os braços por buracos errados. O modelo e o corte da camisa anti-suor dificultaram esse ritual. As camadas de pano formavam várias camisas, de modo que Edmilson não conseguia livrar-se de tantos forros com dobras complicadas. O tempo foi passando, e uma mera troca de camisa tornou-se uma catimba absurda. Foi meio minuto de graça num lance meio fantástico, que me fez lembrar o conto "No se culpe a nadie", de Julio Cortázar. O título do livro vem a calhar: Final do jogo. Não sei se Edmilson sentiu a angústia do personagem de Cortázar. Mas às vezes, no futebol e na literatura, o imprevisível e o absurdo aparecem com ar de graça. ${ }^{32}$

Vemos assim que o universo polifônico da crônica brasileira ao longo dos mundiais de futebol reflete a diversidade que advém com a presença de um contingente de profissionais que recusam as obrigações do discurso canônico jornalístico e que, ao mesmo tempo, recusam a formulação padrão que os "entendidos" do futebol procuram explorar, ao circunscrever suas análises apenas no âmbito pragmático da disputa. Os cronistas, com a diversidade de seus textos, superam assim a tirania dos discursos segmentados.

\section{Considerações finAIS}

A presença de escritores na cobertura das Copas do Mundo de futebol adquiriu uma importância ímpar no Brasil a partir da década de 1980. Colunas e crônicas superpovoaram as coberturas dessas competições e foram responsáveis especialmente pela manutenção do discurso literário nas páginas da imprensa esportiva brasileira.

\footnotetext{
${ }^{31}$ Milton Hatoum. Folha de S.Paulo, 17 jun. 2002.

${ }^{32}$ Milton Hatoum. Folha de S.Paulo, 3 jul. 2002.
} 
A primazia de poder eleger temas e ângulos de discussão é levada às últimas conseqüências pelos colunistas e cronistas, que acabam assumindo, mais do que meros repórteres ou redatores, a imagem dos depositários da sabedoria milenar. Colunas e crônicas representam, por conseguinte, uma espécie de oráculo, de consulta esotérica, que o leitor visita cotidianamente para referendar ou contrastar suas próprias opiniões. O recurso utilizado pelos jornais de chamar profissionais de outras editorias para comentar as Copas do Mundo tem o intuito justamente de oferecer outra visão sobre o futebol, diferentemente das ideias comuns presentes nas análises dos jornalistas esportivos.

Em 2002, o dialogismo e a polifonia do discurso dos cronistas permaneceram e fortaleceram-se pelas questões ligadas ao tempo da escrita, já que não se podia acompanhar o tempo dos acontecimentos. Os cronistas e colunistas de futebol perpetuaram assim a singularidade do gênero, reatualizando-o e reconstruindo-o em outra esfera. Contrariando as várias definições de que a crônica, por ser efêmera, tem sua duração circunscrita ao tempo do jornal, os textos aqui analisados mantêm-se firmes e atuais mesmo com o passar dos anos.

No jornalismo esportivo brasileiro, enfim, esses "pensadores do cotidiano e da vida imediata" têm sido os principais responsáveis por manter o futebol ao rés do chão, isto é, ao nível de leitores e torcedores, na medida em que se ajustam à sensibilidade do cotidiano por meio de uma linguagem própria do dia a dia. Ao mesmo tempo, são os responsáveis por enriquecer o discurso da imprensa por meio de relatos em que se destaca o trabalho de construção literária e que superam as ortodoxias ditadas pelo próprio texto jornalístico. E, na criação dessas palavras sobre o jogo, os cronistas fazem prevalecer o divertido jogo com as palavras, o que reproduz nas páginas dos jornais, de quatro em quatro anos, a festa e a magia que a seleção brasileira cumpre ao longo dos Mundiais de futebol.

\section{A}

\section{RÉ SUMÉ}

La Coupe du Monde 2002, joué au Japon et Corée du Sud, a représenté un défi sans précédent pour la couverture du journalisme brésilien: comment offrir un contenu attrayant pour le lecteur avant l'heure de l'édition et publication des journaux, ce qui précédait en quelques instants l'horaire de réalisation des matches du tournoi. Une stratégie de lutte contre l'éphémère du temps des nouvelles étaient la convocation d'écrivains, de chroniqueurs et écrivains des cahiers de culture. Invités à commenter l'événement, ces professionnels ont pris leurs distances de la référence journalistique simple - et, ainsi, les faits et les nouvelles ont commencé à acquérir des contours reconstruits par la subjectivité et la création littéraire.

\section{MOTS-CLÉS}

Chronique littéraire, la Coupe du Monde de Football 2002, journalisme brésilien 


\section{REFERÊNCIAS}

AGUIAR E SILVA, Vítor Manuel. Teoria da literatura. Coimbra: Liv. Almedina, 1986. ALMEIDA PRADO, Décio de. Latejando com o futebol. In: . Seres, coisas, lugares. São Paulo: Companhia das Letras, 1997. p. 202-208.

ARRIGUCCI JR., Davi. Fragmentos sobre a crônica. In: ARRIGUCCI JR., Davi. Enigma e comentário. São Paulo: Companhia das Letras, 1987. p. 51-66.

BARTHES, Roland. Introdução à análise estrutural da narrativa. In: . et. al. Análise estrutural da narrativa. Trad. Maria Zélia Barbosa Pinto. Petrópolis: Vozes, 1971. p. 19-60. BAUDRILLARD, Jean. Mirroir du terrorisme. In: . La transparence du mal: essais sur les phénomènes extrêmes. Paris: Galilée, 1990. p. 83-89.

CALABRESE, Omar. A idade neobarroca. Trad. Carmen de Carvalho e Artur Morão. Lisboa: Edições 70, 1988.

CANDIDO, Antonio. A vida ao rés-do-chão. In: . Recortes. São Paulo: Companhia das Letras, 1993. p. 23-29.

MAINGUENEAU, Dominique. Pragmática para o discurso literário. Trad. Marina Appenzeller. São Paulo: Martins Fontes, 1996.

RONÁI, Paulo. Um gênero brasileiro: a crônica. In: PRETO-RODAS, Richard. A.; HOWER, Alfred; PERRONE, Charles A. (Ed.). Crônicas brasileiras: nova fase. Gainesville, Florida: University Press of Florida, 1994. p. 213- 217. 